R. H. Follis, jun., describes histochemical work which has mainly been published ${ }^{1}$, and with $M$. D. Levine describes a lecithinase in fœtal pig cartilage homogenates which splits lecithin. They find that neutral fat and water-soluble phosphate are formed, the latter being presumed to arise by the action of phosphatase on phosphocholine. Levine, P. S. Rubin, Follis and J. E. Howard show by means of the toluidine blue metachromatic reaction, the periodic acid - leucofuchsin reaction and the silver staining of calcium salts that the granular material deposited in subcutaneous tissue of a patient with calcinosis universalis consists of calcium salts held in a matrix identical in staining properties with calcified cartilage matrix. They also report similar studies on cartilage and bone.

The evidence of isotope work relating to exchange of calcium and phosphorus between bone salt and solution is reviewed by $H$. C. Hodge, and R. I. Lienke, G. Cullen and W. D. Armstrong describe the distribution of calcium-45 after continuous intra. peritoneal administration of ${ }^{45} \mathrm{CaCl}_{2}$ to rats. With the same technique Armstrong and S. H. Zbarsky examine the distribution of carbon-14 after giving $\mathrm{Na}_{2}{ }^{14} \mathrm{CO}_{3}$ continuously to a rat for 117 hours. Armstrong and J. Schubert" show that "the greater part of ${ }^{14} \mathrm{C}$ deposited in bone is fairly rapidly removed".

On the subject of gastric secretion, C. F. Code, C. M. Blackburn, G. B. Livermore, jun., and H. V. Ratke describe a procedure for assaying inhibition of gastric secretion in the dog, and with it have found inhibitory activity in extracts of hog gastric mucin, in human gastric juice ${ }^{3}$ and in saliva. W. B. Patterson and D. Stetten, jun., put forward the hypothesis that gastric mucosa produces a hydrogen-ion gradient by means of a stratification of the various respiratory enzymes across the cell, with dehydrogenases toward the surface and cytochrome oxidase and carbonic anhydrase toward the blood supply.

Energy transfer is considered by O. H. Schmitt, who suggests very plausibly as an alternative to highenergy phosphate bonds as carriers that energy is transferred and stored within the cell in the form of electrostatic potential gradients at interfaces. His objection to coupled reactions on the grounds that they involve multi-body collisions seems, however, rather thin, since many such reactions are known to occur at reasonable rates ${ }^{4}$.

In the discussion on intermediary metabolism, H. G. Wood shows that, on giving to fasted rats formate labelled with carbon-14 and glycine labelled with carbon-13 in the carboxyl radical, the isotope distribution in the liver glycogen formed supports the hypothesis ${ }^{5}$ that these substances form serine, which then goes to glycogen via pyruvate. Serine isolated from the liver protein also shows the expected isotope distribution. S. Gurin describes isotope experiments, with phenylalanine labelled in either the side-chain or the ring, which confirm that the side-chain shifts during metabolism and that a carbon atom from the ring becomes the $\gamma$ carbon of the acetoacetate formed. Leucine is similarly shown to form acetone and twocarbon fragments.

Finally, there are the papers on steroid metabolism. F. Albright and his collaborators show that on giving adrenocorticotrophin to patients there is a marked transitory potassium excretion, and an excessive retention of sodium suggesting its entry into cells. There is also a steady loss of nitrogen without commensurate loss of phosphorus and potassium; it is suggested that the retention of the latter is associated with glycogen retention. L. Wilkins and R. A. Lewis find that adrenocorticotrophin given to patients with Cushing's syndrome has much the same effect as in normal persons, whereas in cases of adreno-genital syndrome it causes marked sodium and chlorine loss and some loss in weight; they suggest that the adrenals may secrete a hormone causing salt loss. In another paper they discuss the effect of various testosterone derivatives on adrenal weight and cholesterol content. Methods of estimating urinary corticoid activity are compared by E. H. Venning; and D. K. Halvorsen describes the effect of sex hormones on muscle and bone tissue atrophy in the hind limbs of mice paralysed by spinal cord hemisection, and on bone total and ash weights when given throughout the life of mice. R. Pearcy

1 Follis, R. H., jun., and Berthrong, M., Amer. J. Path., 24, 685 (1948). 2 Schubert, J., and Armstrong, W. D., J. Biol. Chem., 177, 521 (1949). ${ }^{3}$ Brunschwig, A., et al., J. Clin. Invest., 18, 415 (1939).

-Dixon, M., "Multi-Enzyme Systems" (Cambridge University Press, $1949)$.

s Sakami, W., J. Biol. Chem., 176, 995 (1948).

\section{WATTLE RESEARCH INSTITUTE, SOUTH AFRICA}

$T$ HE Wattle Research Institute at Pietermaritzburg is a new Institute under three different organisations-the South African Wattle Growers Union, the University of Natal, and the Union Department of Forestry-and it has recently published a first report for 1948*. Since the work of the Institute has scarcely been begun, the publication of a report may appear to be premature; but the time is opportune to place on record details of the conception and development of the idea and its fulfilment.

The constitutional relation of the Institute to the three organisations is also of interest to study. The idea was started some time about 1937, when a number of growers, under the stimulus of discussions with the research officers of the Department of Forestry, began to take an interest in the idea of such an Institute. It was felt that the importance of the industry merited the establishment of a research organisation devoted exclusively to the improvement of wattle cultivation and tannin production and into which all the various lines of research on wattle could be gathered as a co-ordinated whole.

'The opening phases of the establishment of this important Research Institute are curiously like those followed when the great Forest Research Institute at Dehra Dun, India, was first commenced in 1906-7.

As is stated in the foreword of this report, "The research programme presented is of a tentative and very fluid nature designed only to crystallize early ideas. It will be modified and extended as necessary when the various lines of work open out and take shape and as new problems become apparent." That is the way the research officers began their operations at Dehra Dun. Even during the First World War the Government of India soon recognized its great usefulness, and, before the Second World War broke out, a mighty research organisation had been built up. Let us hope that a similar record of successful expansion and progress will be the lot of the Wattle Research Institute in South Africa.

* University of Natal: Wattle Research Institute. Report for * University of Natal: Wattle Research Institute, Report for
1948. Pp. 26. (Pietermaritzburg: Wattle Research Institute, 1948.) 